\title{
Pretreatment of Automotive Shredder Residues, Their Chemical Characterisation, and Pyrolysis Kinetics
}

\author{
Sandhya Kuruvalan Vijayan ${ }^{1}{ }^{10}$, Mahmud Arman Kibria ${ }^{1}$, Md Hemayet Uddin ${ }^{2}$ and Sankar Bhattacharya ${ }^{1, *}$ \\ 1 Chemical Engineering Department, Monash University, Clayton, VIC 3800, Australia; \\ sandhya.vijayan@monash.edu (S.K.V.); mahmud.kibria@monash.edu (M.A.K.) \\ 2 Melbourne Centre for Nanofabrication, Clayton, VIC 3800, Australia; hemayet.uddin@nanomelbourne.com \\ * Correspondence: sankar.bhattacharya@monash.edu
}

Citation: Vijayan, S.K.; Kibria, M.A.; Uddin, M.H.; Bhattacharya, S.

Pretreatment of Automotive Shredder Residues, Their Chemical

Characterisation, and Pyrolysis

Kinetics. Sustainability 2021, 13, 10549.

https://doi.org/10.3390/

su131910549

Academic Editor: Isabella Pecorini

Received: 2 August 2021

Accepted: 20 September 2021

Published: 23 September 2021

Publisher's Note: MDPI stays neutral with regard to jurisdictional claims in published maps and institutional affiliations.

Copyright: (C) 2021 by the authors. Licensee MDPI, Basel, Switzerland. This article is an open access article distributed under the terms and conditions of the Creative Commons Attribution (CC BY) license (https:/ / creativecommons.org/licenses/by/ $4.0 /)$.
Abstract: Automotive Shredder Residue (ASR), a waste when metals are mostly removed from end-of-life vehicles, has constituents similar to municipal solid waste (MSW) consisting of plastics, rubber, textiles, and some metals. The processing of ASR is a challenge due to its heterogeneous nature, making feeding to a reactor difficult. In this work, a new procedure of ASR pretreatment is proposed to bring particulate nature in the sample for easier feeding during pyrolysis. The thermal breakdown characteristics of the pretreated ASR solids under slow pyrolysis conditions were assessed in a thermogravimetric analyser following the International Confederation for Thermal Analysis and Calorimetry (ICTAC) kinetics committee recommendations. The effect of particle sizes and heating rates were studied at temperatures up to $800{ }^{\circ} \mathrm{C}$ at different heating rates of 2,5 , and $10{ }^{\circ} \mathrm{C} / \mathrm{min}$ for three particle sizes, 38-63 $\mu \mathrm{m}, 63-90 \mu \mathrm{m}$, and 90-106 $\mu \mathrm{m}$, and the kinetic data were derived. The volatiles emitted during pyrolysis were characterized by Diffuse Reflectance Infrared Spectroscopy (DRIFTS). We also developed an algorithm for the selection of heating rate during the pyrolysis of the pretreated ASR. The DRIFTS results, kinetic data, and heating rate for the selected particle sizes are useful for the development of a pyrolysis process for pretreated ASR.

Keywords: automotive shredder residue; pretreatment; DRIFTS; kinetic model analysis; pyrolysis

\section{Introduction}

There are about 50 million units of end-of-life vehicles (ELV) per year which generate 50 million tonnes of waste annually worldwide [1]. In recycling ELVs, there are three phases in ELV pre-processing, namely de-pollution, dismantling, and shredding. Initially, in the depollution and dismantling stages, the engine and tires are removed, followed by the removal of batteries, fluid, and fuel. Finally, the final car hulk, which constitutes $60 \%$ of the weight, is shredded in a shredding unit. Furthermore, the shredded materials are taken to magnetic separators for the segregation of ferro-metals. As a result, the ferrous fraction represents approximately $70-75 \%$ of the total shredded output, while non-ferrous metals represent about 5\%. The remaining 20-25\% fraction is referred to as automotive shredder residue (ASR).

ASR is an inevitable waste at the end-of-life vehicles' treatment processes [2]. ASR consists of plastics (19-35\%), textile (10-40\%), rubber $(20 \%)$, some metals $(8 \%)$, wood (2$5 \%$ ), and other unspecified materials [3]. There are no existing technologies to process this type of waste, and these ASR fractions are often disposed of in landfills as municipal solid waste (MSW). The leachate from the ASR landfills has a significant presence of organic compounds and heavy metals, and it is a threat to the environment [4-6]. ASR had not been traditionally considered for energy conversion until a study was conducted to investigate energy recovery from ASR by co-incinerating it with MSW [7]. It was found that ASR can be converted into energy as it contains a high heating value. However, processing ASR via incineration emits toxic gases, which will cause pollution and harm to the environment. 
Compared with incineration, pyrolysis provides a more environmentally benign and promising solution to ASR processing as pyrolysis does not involve oxygen in the process, producing higher heating value fuels [8,9]. However, the pyrolysis product yield depends upon the composition of ASR and the operating parameters. Due to limited thermal stability, the chemical bonds break when heat is applied, which leads to the formation of smaller molecules, which then interact, further generating more abundant compounds. This process is also known as reverse polymerization, polymer cracking, or thermal depolymerization. The higher-energy-density products obtained during the pyrolysis process are volatile gases and carbonaceous solids (char). Subsequent to that study [7], several other studies conducted ASR pyrolysis in the temperature range from 450 to $800^{\circ} \mathrm{C}$ [10-15]. The products obtained from ASR pyrolysis, such as non-condensable gases and condensable (pyrolysis-oil), can be further processed to recover energy. However, the carbonaceous solids obtained after the ASR pyrolysis process may contain residual metal content if ELVs are not fully stripped of metals, which can also cause problems at their disposal [16]. Hitherto, researchers have developed a treatment process only for plastics components of ASR after sorting them for energy conversion, but not for other components of the ASR waste. Different separation techniques, namely, froth flotation, static hydrodynamic separation, or thermo-mechanical sorting, were used to sort plastics from ASR [17]. The sorted plastics were then converted into energy by using various thermochemical treatment methods. Previous studies on ASR pyrolysis have mainly focused on converting plastics into energy while ignoring the importance of residual metals that can also be recovered. This is primarily due to the challenges of treating the heterogeneous nature of ASR to be processed in a pyrolysis reactor. As previously mentioned, this fluffy nature makes it difficult to feed the ASR into a reactor. It is important that ASR is pretreated to homogenise the particulate nature before it is processed in the pyrolysis reactor.

However, to the best of the authors' knowledge, no kinetic data on the pretreated ASR can be found in the literature. Information on ASR pyrolysis kinetics is essential to establish the process parameters, which are also dependent on the chemical composition of the raw material. The ICTAC kinetic committee outlined the guidelines for evaluating kinetic parameters such as the activation energy, pre-exponential factor, and reaction model [18]. They also recommended that the model fitting methods could be reliable as long as the models under different temperature programs are fitted simultaneously to multiple data sets obtained.

In this work, we propose a method to homogenise the ASR particulate nature and establish the kinetics of the pretreated ASR for the pyrolysis process. We first introduced heat treatment for the ASR to soften the plastics and further ground. We then report the physicochemical characterisation of the pretreated ASR material through X-ray Diffraction (XRD), electron microscopy (SEM), X-Ray Fluorescence (XRF), and Diffuse Reflectance Fourier Transform Spectroscopy (DRIFTS). This is followed by the analysis of the mass loss profiles of pretreated ASR obtained by thermogravimetric analysis following the ICTAC kinetics committee recommendations for different particle sizes and heating rates. A kinetic model was used to estimate the kinetic parameters-activation energy (Ea) and preexponential factor (A). Finally, an algorithm for the selection of heating rates for pretreated ASR pyrolysis was developed.

This is the first-of-its-kind work proposing a pretreatment method for ASR followed by physicochemical characterisation of the pretreated ASR and their kinetic analysis to determine the pyrolysis kinetic parameters for scaling-up purposes.

\section{Materials and Methods}

For this study, Automotive Shredder Residue (ASR) was obtained from a commercial supplier in Victoria, Australia. The ASR (as received) was a mixture that contained different particle sizes with plastics and metals, as seen from Figure 1a. Feeding this ASR (as received) into the pyrolysis reactor was difficult as it was heterogeneous in nature and could not 
be ground and was non-uniform particle size. To ensure easier feeding to the pyrolysis reactor, developing a particulate nature in the sample; therefore, the ASR (as received) was pretreated in a horizontal tubular furnace as described below.

\subsection{Pretreatment of $A S R$}

The volatile content in the ASR (as received) arises mainly from its plastics content. The plastics start to soften around $200{ }^{\circ} \mathrm{C}$ [19], and the devolatilization of any plastic components starts above $280^{\circ} \mathrm{C}$ [20]. Hence, the temperature for ASR pretreatment was chosen below the devolatilization temperature of plastics to avoid loss of volatiles. The pretreatment includes heating the ASR sample to $200{ }^{\circ} \mathrm{C}$ in a horizontal tubular furnace (Model: HTHTF80/15: P059) at a slow heating rate of around $20^{\circ} \mathrm{C} / \mathrm{min}$ and holding it there for one hour. Subsequently, the samples were cooled and then ground. The sample was then sieved to particle sizes in the range from 38-63 $\mu \mathrm{m}, 63-90 \mu \mathrm{m}$, and 90 $106 \mu \mathrm{m}$. Figure 1 shows the ASR (as received) and after pretreatment. Clearly, the fluffy heterogeneous nature in the as-received sample is replaced by a particulate nature in the pretreated sample. The pretreatment process also made grinding the sample possible and subsequent sieving was easier.

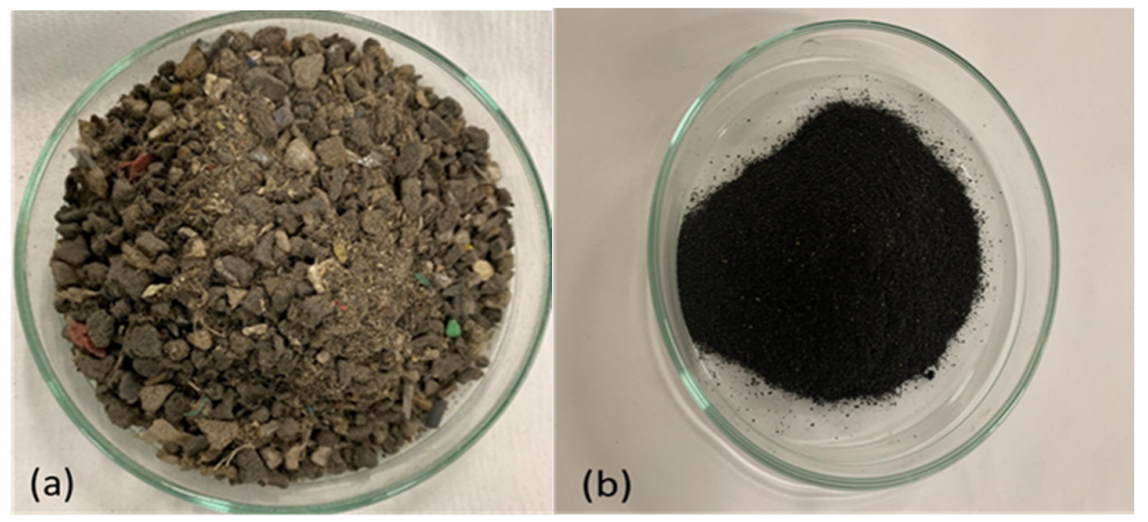

Figure 1. (a) ASR (as received), (b) Pretreated ASR.

\subsection{Sample Characterization}

The proximate analysis of the ASR sample was determined in a thermo-gravimetric analyser (Model STA 449F3, NETZSCH, Selb, Germany) according to AS2434 standard. Approximately $10 \pm 1 \mathrm{mg}$ of ASR sample (both pretreated and raw) was taken to analyse in the TGA to obtain a simultaneous mass loss and differential mass profile with respect to time and temperature. The conditions were carried out initially in a nitrogen environment, with a heating rate of $10^{\circ} \mathrm{C} / \mathrm{min}$ up to $105^{\circ} \mathrm{C}$, isothermal at $105^{\circ} \mathrm{C}$ for $20 \mathrm{~min}$, then heating up to $900{ }^{\circ} \mathrm{C}$ at $10^{\circ} \mathrm{C} / \mathrm{min}$, isothermal at $900^{\circ} \mathrm{C}$ for $7 \mathrm{~min}$. Finally, it was cooled to $550{ }^{\circ} \mathrm{C}$ at $50{ }^{\circ} \mathrm{C} / \mathrm{min}$ in a nitrogen environment and isothermal in the air at $550{ }^{\circ} \mathrm{C}$ for $40 \mathrm{~min}$. A blank correction was also performed with the same process condition to be subtracted from the measurement data.

The ultimate analysis was carried out in a FLASH 2000 CHNS analyser (Thermo Scientific, Milan, Italy) operating based on dynamic flash combustion for both ASR (as received) and the pretreated ASR.

The ash composition of the pretreated ASR sample was analysed using X-Ray Fluorescence spectroscopy (XRF-EDX-720: Shimadzu Corp, Kyoto, Japan) with a voltage of $15-50 \mathrm{kV}$ in the air atmosphere. The resulting fluorescence spectra was used to determine the elements in the sample from Na to U. Before XRF analysis, ash was prepared from the parent ASR sample at $900^{\circ} \mathrm{C}$ for $6 \mathrm{~h}$ in a muffle furnace.

X-ray diffraction measurements were conducted in Rigaku MiniFlex 600 operating in

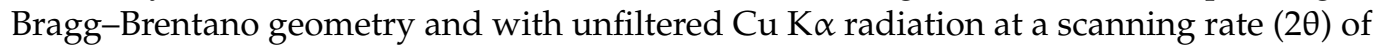


$1.3^{\circ} \mathrm{min}^{-1}$ over a range $2 \theta=10-80^{\circ}$ to identify crystalline mineral matter. The pretreated ASR was burned at $600^{\circ} \mathrm{C}$ for $2 \mathrm{~h}$ in a muffle furnace to remove the amorphous carbon.

Scanning Electron Microscopy coupled with an Energy Dispersive Spectroscopy (SEMEDX) was conducted using Phenom XL to observe the morphologies and semi-quantitative analysis of the ASR ash and pyrolysis residue samples.

DRIFTS were obtained using a Perkin Elmer (Beaconsfield, UK) Spectrum instrument mounted with a Praying Mantis DRIFTS cell fitted with ZnSe windows. The sample $25 \mathrm{mg}$ (approx.) was loaded into the reactor to collect the spectra (single-beam mode) from room temperature to $600^{\circ} \mathrm{C}$ at every $2{ }^{\circ} \mathrm{C}$ as an aggregate of 32 scans in the range of $450-4000 \mathrm{~cm}^{-1}$ and a resolution of $4 \mathrm{~cm}^{-1}$.

The zeta potential of pyrolysis char and its ash from pretreated ASR was measured by Malvern Zetasizer Nano ZS. Approximately $5 \mathrm{mg}$ of the sample particles was dispersed in $750 \mu \mathrm{L}$ of ethanol $(1 \mathrm{mg} / \mathrm{mL})$ and the ash of the same in $5 \mathrm{ml}$ of milliQ water in a vortex. Then, the dispersion was transferred into a disposable zeta potential sample cell for the measurement at room temperature of $25^{\circ} \mathrm{C}$. The zeta potential values were averaged from more than three measurements.

\subsection{Thermogravimetric Analysis (TGA) Procedure for Kinetic Study}

Pyrolysis experiments for kinetic analysis and effects of heating rate and particle size were performed in a thermogravimetric analyser. The pyrolysis conditions for the investigations were according to ICTAC kinetics committee recommendations [21]. For non-isothermal pyrolysis experiments, approximately $6 \mathrm{mg}$ of pretreated ASR sample is spread on the alumina crucible for each experiment to reduce the mass transfer and internal heat transfer effects. The sample is heated in a nitrogen atmosphere at a flow rate of $100 \mathrm{~cm}^{3} \mathrm{~min}^{-1}$ to maintain steady pyrolysis and prevent combustion of the sample. The temperature was programmed between ambient $\left(25^{\circ} \mathrm{C}\right)$ to $800^{\circ} \mathrm{C}$ at different heating rates of 2,5 , and $10^{\circ} \mathrm{C} / \mathrm{min}$.

\subsection{Pyrolysis Kinetics}

The general kinetic models are used to describe the overall thermal degradation behaviour of the sample. The focus of this section was to obtain the kinetics parameters such as activation energy and pre-exponential factor of pretreated ASR samples. The kinetic model of pyrolysis can be expressed as:

$$
\frac{\mathrm{dX}}{\mathrm{dt}}=k(1-X)^{n}
$$

where $X$ is the degree of the conversion rate of the decomposed sample, $k$ is the reaction rate constant (temperature functions), and $n$ is the order of the reaction

The conversion rate $X$ is calculated by the following expression:

$$
X=\frac{w_{o}-w}{w_{o}-w_{f}}
$$

where $w_{o}$ is the initial mass of the sample, $w$ is the sample mass at present; and $w_{f}$ is the final mass of the sample.

The thermal decomposition of ASR can be expressed [22] as:

$$
\text { Solids }=\mathrm{y}(\text { Volatiles })+(1-\mathrm{y}) \text { Char }
$$

From the above Equation (3), the solid is the pretreated ASR, volatiles are the gases evolved during the reaction, char is the residual formed after decomposition of the solid, and $y$ is the yield of gases produced. The devolatilization rate can be expressed according to [23]:

$$
r=\frac{d W}{d t}=-\frac{d W}{y d t}=-\frac{d W}{(1-y) d t}=-k\left(w-w_{f}\right)^{n}
$$


where $k$ is the reaction rate constant, and its temperature dependence is described by the Arrhenius equation as follows:

$$
k=A e^{-\mathrm{E}_{a} / \mathrm{RT}}
$$

where $A$ is the pre-exponential factor (frequency factor), $\mathrm{E}_{a}$ is the apparent activation energy, $\mathrm{R}$ is the universal gas constant $\left(8.314 \mathrm{~J} \mathrm{~mol}^{-1} \mathrm{~K}^{-1}\right)$, and $\mathrm{T}$ is the temperature.

Substituting $k$ Equation (5) in (4) yields:

$$
\frac{\mathrm{dW}}{\mathrm{dt}}=A e^{-\mathrm{E}_{a} / \mathrm{RT}}\left(w-w_{f}\right)^{n}
$$

Rearranging Equation (6) in terms of temperature derivatives, one can obtain:

$$
\frac{d W}{d T}=\beta A e^{-E_{a} / R T}\left(w-w_{f}\right)^{n}
$$

where $\beta$ is the temperature derivative and can be defined as $\beta=d T / d t$ :

$$
\frac{\frac{d W}{d T}}{\left(w-w_{f}\right)^{n}}=\beta A e^{-\mathrm{E}_{a} / \mathrm{RT}}
$$

In order to predict kinetic parameters, a linearized form of Equation (7) is considered. Hence, taking a natural logarithm on both sides:

$$
\ln \frac{d W}{d T}-n \ln \left(\left(w-w_{f}\right)=\ln \frac{A}{\beta}-\frac{\mathrm{E}_{a}}{\mathrm{RT}}\right.
$$

Plotting $\ln \frac{d W}{d T}-n \ln \left(\left(w-w_{f}\right)\right.$ vs. $1 / \mathrm{T}$ with an optimized reaction order will produce a straight line whose intercept is $\ln \frac{A}{\beta}$ and having a slope of $-\frac{\mathrm{E}_{a}}{\mathrm{R}}$.

\section{Results and Discussion}

The results of the experiments and analysis are presented and discussed in this section.

\subsection{Properties of ASR (as Received) and Pretreated ASR}

The chemical properties of the ASR (as received) and the pretreated ASR, such as the proximate, ultimate analysis, and ash composition, have been carried out in triplicates, and the average values are listed in Table 1 . The volatile matter remains mostly unaltered after the ASR pretreatment and is found to be in the same range from $54-74 \%$ as reported in the literature [24-26]. The ash content in the pretreated ASR was 33\% contributed mainly by the metals present in the raw material. As seen, the fixed carbon content both for the pretreated and raw ASR samples was found to be in negligible amounts. The very low fixed carbon in the pretreated ASR means that the samples are not appropriate for gasification. As a consequence, pyrolysis should be chosen for the energy recovery process. The ash composition analysed by an XRF analyser resulted in $\mathrm{SiO}_{2}(47.23 \mathrm{wt} \%), \mathrm{CaO}(12.59 \mathrm{wt} \%)$, $\mathrm{Fe}_{2} \mathrm{O}_{3}(15.91 \mathrm{wt} \%), \mathrm{TiO}_{2}(1.62 \mathrm{wt} \%)$, and $\mathrm{Al}_{2} \mathrm{O}_{3}(7.51 \mathrm{wt} \%)$. The aforementioned results also correspond to ASR elemental composition reported by other authors $[6,27,28]$. Therefore, the pretreatment of ASR at or around $200^{\circ} \mathrm{C}$ temperature minimized further devolatilization of the plastics. In addition, the obtained pretreated ASR resulted in a particulate nature, and the sample could be ground and sieved to a uniform particle size for easier feeding of the pretreated samples to the pyrolysis reactor. 
Table 1. Proximate analysis, ultimate analysis, and ash analysis of ASR (as received) and pretreated ASR.

\begin{tabular}{|c|c|c|c|}
\hline Properties & & ASR (as Received) & Pre-Treated ASR \\
\hline \multicolumn{4}{|c|}{ Proximate analysis (dry basis, wt $\%$ ) } \\
\hline Volatile matter & & $62.24 \pm 17.06$ & $66.83 \pm 8.49$ \\
\hline Fixed carbon & & 0.00 & 0.00 \\
\hline Ash & & $37.76 \pm 17.06$ & $33.12 \pm 8.54$ \\
\hline \multicolumn{4}{|c|}{ Ultimate analysis (dry basis-ash free, $w \mathrm{t} \%$ ) } \\
\hline Carbon $(\mathrm{C})$ & & $53.81 \pm 5.21$ & $60.16 \pm 4$ \\
\hline Hydrogen $(\mathrm{H})$ & & $8 \pm 1.06$ & $8.72 \pm 1.53$ \\
\hline Nitrogen $(\mathrm{N})$ & & $1.63 \pm 0.18$ & $2.14 \pm 1.06$ \\
\hline Sulphur (S) & & $0.04 \pm 0.06$ & $0.08 \pm 0.12$ \\
\hline * Oxygen $(\mathrm{O})$ & & $36.52 \pm 4.50$ & $28.91 \pm 6.34$ \\
\hline \multicolumn{4}{|c|}{ Ash composition (wt\%. dry basis) } \\
\hline & $\mathrm{Na}_{2} \mathrm{O}$ & & 1.89 \\
\hline & $\mathrm{MgO}$ & & 2.43 \\
\hline & $\mathrm{Al}_{2} \mathrm{O}_{3}$ & & 7.51 \\
\hline & $\mathrm{SiO}_{2}$ & & 47.23 \\
\hline & $\mathrm{SO}_{3}$ & & 2.63 \\
\hline & $\mathrm{K}_{2} \mathrm{O}$ & & 0.81 \\
\hline & $\mathrm{CaO}$ & & 12.59 \\
\hline & $\mathrm{TiO}_{2}$ & & 1.62 \\
\hline & $\mathrm{MnO}$ & & 0.78 \\
\hline & $\mathrm{Fe}_{2} \mathrm{O}_{3}$ & & 15.91 \\
\hline & $\mathrm{ZnO}$ & & 5.69 \\
\hline & $\mathrm{CuO}$ & & 0.19 \\
\hline & $\mathrm{BaO}$ & & 0.73 \\
\hline
\end{tabular}

* Oxygen calculated by difference.

It is important to recognise that the ASR is primarily heterogeneous in nature, and therefore it is expected that there will be some difference in composition among the samples from different batches. However, the pretreatment process, apart from introducing a particulate nature, imparts some degree of "homogeneity" within the overall mixed samples.

\subsection{XRD Analyses of Pretreated ASR}

The XRD pattern of the pretreated ASR is shown in Figure 2. The broad diffraction peaks at $26.34,29.78,35.24$, and $44.68^{\circ}$, corresponding to $\mathrm{SiO}_{2}, \mathrm{CaO}, \mathrm{Al}_{2} \mathrm{O}_{3}$, and $\mathrm{CuO}$, were also reported in ASR [29]. Silica species is the dominant phase in the pretreated ASR ash, having $\beta$-quartz as a majority in the detected phase. The other sharp peaks correspond to $\mathrm{Fe}_{2} \mathrm{O}_{3}, \mathrm{Al}_{2} \mathrm{O}_{3}$, and $\mathrm{ZnO}$, believed to exist as residuals after recovering steel and iron and non-ferrous scrap post shredding of ELVs. Small peaks corresponding to $\mathrm{TiO}_{2}$ were also found in the sample. Titania is combined with plastics for durability in automobiles [28]. We found that the XRD results correlated with the XRF analysis of the ash prepared from the pretreated ASR. This also indicates that the residual metal content, as expected, remains unaltered after the pretreatment process. These metals can be recovered from the ash following the pyrolysis of the pretreated ASR. 


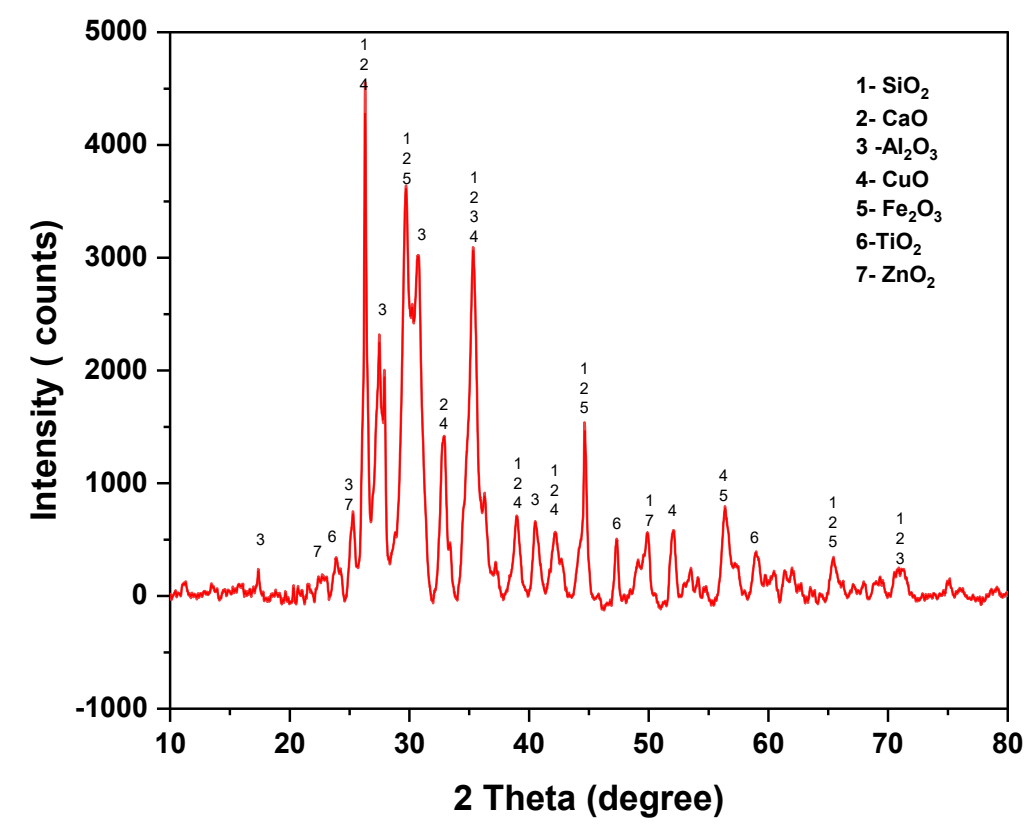

Figure 2. X-ray diffractogram of the ash prepared from the pretreated ASR.

\subsection{SEM-EDX Analysis}

Figure 3 presents the elemental composition at a specific location within the particles of the pretreated ASR. As seen, the particles are non-porous in structure. This might be due to the melting characteristics of the present plastics within the sample. Table 2a represents the point analysis of pretreated ASR having metals such as $\mathrm{Si}, \mathrm{Ca}, \mathrm{Mg}$, and Ti in major composition. In addition, the presence of $\mathrm{Fe}, \mathrm{Cu}$, and $\mathrm{Zn}$ are detected at specific points. The presence of carbon shown in Figure 3 is the carbon content from the plastics in the pretreated ASR. Moreover, the mapping of the individual particle (Figure 3b) shows the scattered distribution of metals. These metals' contents were also detected in the crystalline mineral matter composition, as discussed in Section 3.2. The results from SEM-EDX confirm the presence of residual metals in the pretreated ASR. For the recovery of these metals from the residues of pretreated ASR pyrolysis, further processing is required.

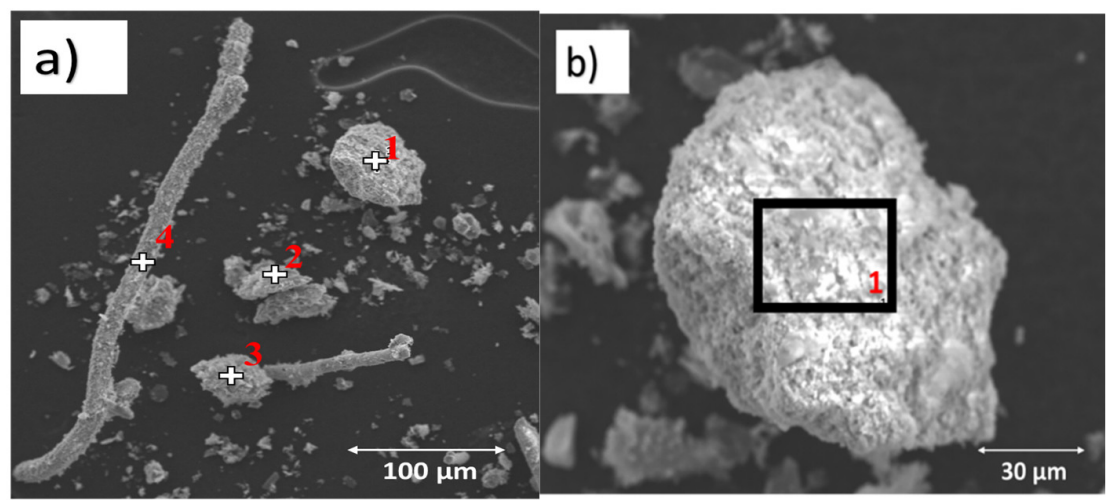

Figure 3. Scanning electron micrographs and EDX spectra for (a) pretreated ASR (b) selected individual particle of pretreated ASR. 
Table 2. (a) EDX analysis of the pretreated ASR (Figure 3a). (b) EDX analysis on a single particle of the pretreated ASR (Figure 3b).

(a)

\begin{tabular}{llllllll}
\hline \multicolumn{2}{c}{ Point 1 } & \multicolumn{2}{c}{ Point 2 } & \multicolumn{2}{c}{ Point 3 } & \multicolumn{2}{c}{ Point 4 } \\
\hline Element & $\mathbf{w t} \%$ & Element & $\mathbf{w t} \%$ & Element & $\mathbf{w t} \%$ & Element & wt $\%$ \\
\hline $\mathrm{Ti}$ & 26.40 & $\mathrm{O}$ & 50.83 & $\mathrm{O}$ & 41.75 & $\mathrm{O}$ & 55.62 \\
$\mathrm{C}$ & 25.19 & $\mathrm{Si}$ & 16.28 & $\mathrm{Si}$ & 19.79 & $\mathrm{Si}$ & 21.25 \\
$\mathrm{O}$ & 23.62 & $\mathrm{Ca}$ & 15.71 & $\mathrm{C}$ & 14.30 & $\mathrm{Ca}$ & 12.40 \\
$\mathrm{Fe}$ & 12.60 & $\mathrm{Al}$ & 6.90 & $\mathrm{Mg}$ & 11.48 & $\mathrm{Al}$ & 6.35 \\
$\mathrm{Ca}$ & 7.32 & $\mathrm{Mg}$ & 4.69 & $\mathrm{Ca}$ & 7.22 & $\mathrm{Mg}$ & 4.07 \\
$\mathrm{Si}$ & 3.30 & $\mathrm{Fe}$ & 2.71 & $\mathrm{Fe}$ & 3.66 & & \\
$\mathrm{Mg}$ & 1.50 & $\mathrm{Zn}$ & 2.48 & $\mathrm{Ti}$ & 1.80 & & \\
\hline
\end{tabular}

(b)

\begin{tabular}{lc}
\hline & Map $\mathbf{1}$ \\
\hline Element & $\mathbf{w t} \%$ \\
\hline $\mathrm{O}$ & 39.52 \\
$\mathrm{Ti}$ & 26.02 \\
$\mathrm{Fe}$ & 14.51 \\
$\mathrm{Si}$ & 8.82 \\
$\mathrm{Ca}$ & 6.85 \\
$\mathrm{Mg}$ & 4.28 \\
\hline
\end{tabular}

\subsection{DRIFTS Analysis of Pretreated ASR}

The DRIFTS spectra in the wavenumber range of $4000 \mathrm{~cm}^{-1}$ and $1000 \mathrm{~cm}^{-1}$ recorded at temperatures up to $600{ }^{\circ} \mathrm{C}$ are depicted in Figure 4 . The bands observed at $2918 \mathrm{~cm}^{-1}$, and $3670 \mathrm{~cm}^{-1}$ are assigned to the methyl asymmetric $\mathrm{C}-\mathrm{H}$ stretch and $\mathrm{O}-\mathrm{H}$ stretching, respectively. The peak at $2364 \mathrm{~cm}^{-1}$ is assigned to $v(\mathrm{O}-\mathrm{H})$ arising due to hydroxyl groups in the polyurethane. Furthermore, the peaks at 2859 and $1461 \mathrm{~cm}^{-1}$ are assigned to the $\mathrm{C}-\mathrm{H}_{2}$ stretching for polypropylene [30,31]. The difference in the peak shifts is attributed to the phenomena of change in the local geometric arrangement. The characteristic absorption and the corresponding band assignment for the spectra were established in Table 3. These assignments provide insight into the chemical moieties present in the pretreated ASR sample. However, the elements such as silicon, titanium, calcium, magnesium, and zinc identified based on EDX and XRF analysis of pretreated ASR did not appear to have caused any Reststrahlen effect, as also observed in other studies [30]. Therefore, the peaks of the DRIFTS spectra of pretreated ASR are due to polymer components. These findings were also aligned with the thermal decomposition temperature range of the polymers present in the sample which will be discussed in the later section. 


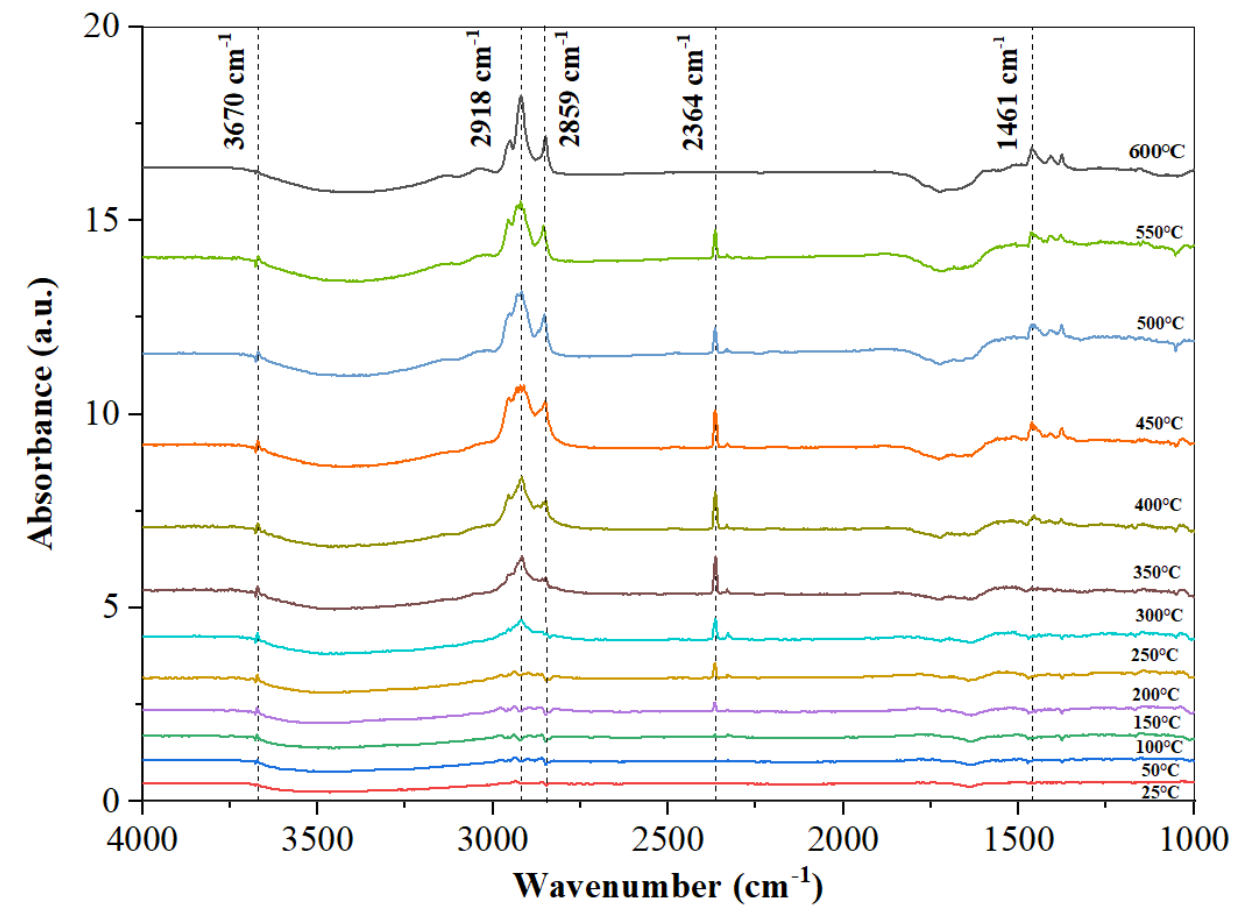

Figure 4. DRIFTS spectra of the pretreated ASR sample.

Table 3. Spectral band assignment observed in DRIFT spectra of pretreated ASR.

\begin{tabular}{cc}
\hline Wavenumber $\mathbf{c m}^{-\mathbf{1}}$ & Assignment \\
\hline 3670 & $\mathrm{O}-\mathrm{H}$ stretching \\
2918 & $\mathrm{CH}_{2}$ asymmetric C-H stretch \\
2859 & $\left(\mathrm{C}-\mathrm{H}_{2}\right)$ stretching \\
2364 & $(\mathrm{O}-\mathrm{H})$ stretching \\
1461 & $\left(\mathrm{C}-\mathrm{H}_{2}\right)$ stretching \\
\hline
\end{tabular}

\subsection{Pyrolysis Behaviour of Pretreated ASR Obtained from TGA}

Plastics are the main organic material present in the ASR that can be converted into volatiles at low temperatures. The plastics found in ASR are polypropylene (PP), polyurethane (PUR), polyamides (PAs), polyethylene (PE), and polycarbonates (PCs), as reported in [32]. The thermal decomposition was performed in a thermogravimetric analyser to study simultaneous mass loss and differential mass profile of the pretreated ASR sample with respect to temperature and time. Figure 5 depicts the decomposition step having the onset, end, and maximum temperatures of pretreated ASR at $216{ }^{\circ} \mathrm{C}, 450{ }^{\circ} \mathrm{C}$, and $373^{\circ} \mathrm{C}$, respectively. This is attributed to the devolatilization of $\mathrm{PE}$ and PP as these species start to decompose at $300^{\circ} \mathrm{C}$ [32]. Moreover, at $216^{\circ} \mathrm{C}$ temperature, the decomposition of pretreated ASR begun with mass loss, and at $450{ }^{\circ} \mathrm{C}$, the mass loss falls to $65 \%$. A similar decomposition temperature range for MSW waste was reported in the literature $[21,33,34]$. Hence, this pretreated ASR can be either co-pyrolysed along with MSW waste or in any existing MSW pyrolysis plants to recover energy. 


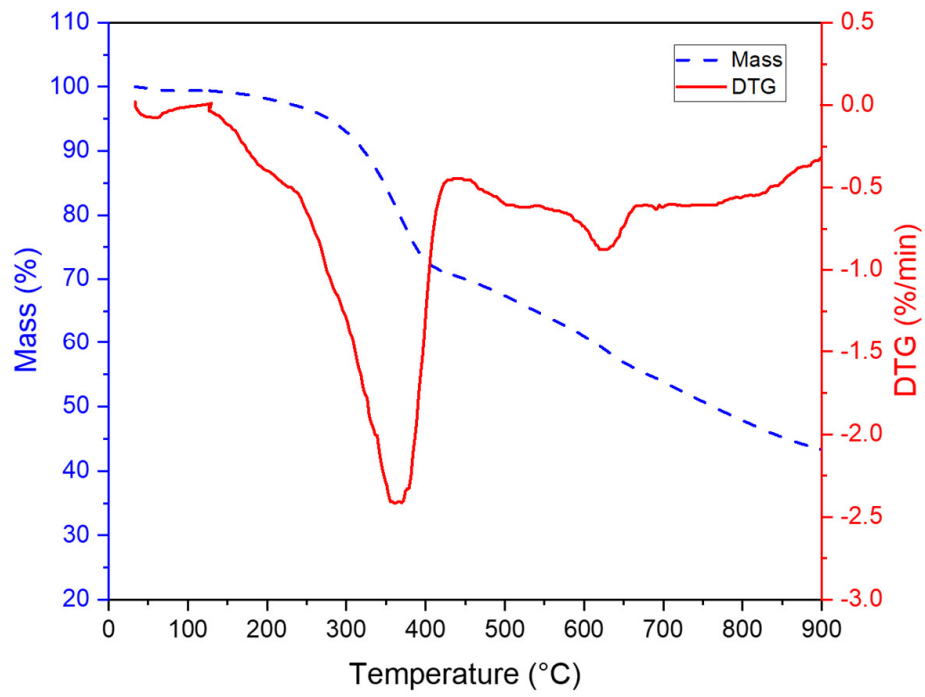

Figure 5. TGA and derivative thermogravimetric (DTG) curve for the pretreated ASR sample $(90-106 \mu \mathrm{m})$.

\subsection{Characterisation of Pyrolysis Residue}

The pyrolysis residue obtained was characterised for its ultimate analysis, DRIFTS analysis, and Zeta potential measurements.

\subsubsection{Ultimate Analysis of the Pyrolysis Residue or Char}

The unreacted carbon compounds are converted into char after the plastics present in the pretreated ASR are devolatilised. As observed from Table 4, the pretreated ASR's hydrogen content decreased when pyrolysis temperature was applied due to the aromatization phenomenon. This led to the char formation that also affects the $\mathrm{C} / \mathrm{H}$ ratio.

Table 4. Ultimate analysis of pyrolysis residue.

\begin{tabular}{cc}
\hline Ultimate Analysis (Dry Basis, wt $\%$ ) & Pyrolysis Residue \\
\hline Carbon (C) & $43.95 \pm 0.98$ \\
Hydrogen (H) & $1.15 \pm 0.25$ \\
Nitrogen (N) & $2.15 \pm 0.24$ \\
Sulphur (S) & $0 \pm 0$ \\
* Oxygen (O) & $17.12 \pm 0.98$ \\
Ash & $35.61 \pm 1.68$
\end{tabular}

* Oxygen calculated by the difference.

\subsubsection{DRIFT Analysis of the Pyrolysis Residue}

It is observed from the DRIFT analysis of the pyrolysis residue, depicted in Figure 6, that sharper bands are obtained. The band observed at $3155,3050 \mathrm{~cm}^{-1}$ is assigned to the $\mathrm{C}-\mathrm{H}$ stretching of alkene groups. The band observed at $2923,2849 \mathrm{~cm}^{-1}$ is assigned to the $\mathrm{C}-\mathrm{H}$ stretching of alkane groups. The band located at $1633 \mathrm{~cm}^{-1}$ is assigned to $\mathrm{C}=\mathrm{C}$ stretching corresponds to a strong alkene group. The band at $3657 \mathrm{~cm}^{-1}$ is $\mathrm{O}-\mathrm{H}$ stretching belonging to the strong alcohol group. The characteristic absorption and the corresponding band assignment for the obtained spectra were established in Table 5. 


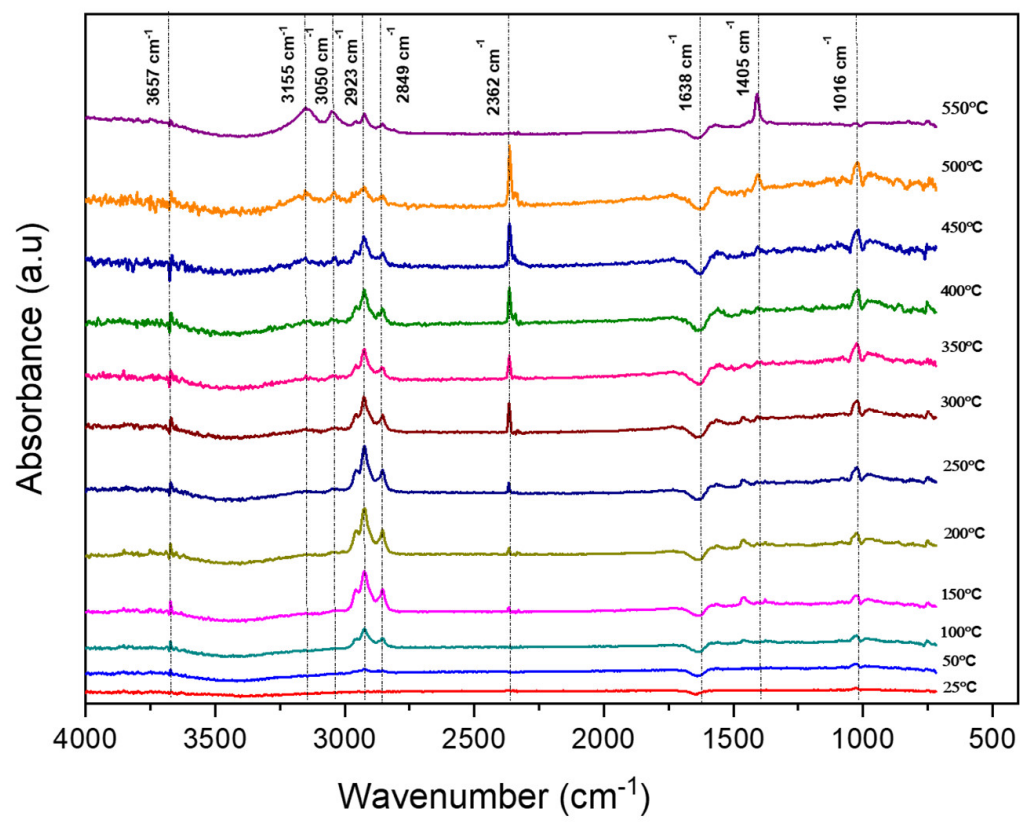

Figure 6. DRIFTS spectra of pyrolysis residue from pretreated ASR.

Table 5. Spectral band assignment observed in DRIFT spectra of pyrolysis residue.

\begin{tabular}{ll}
\hline Wavenumber $\mathbf{~ m}^{-\mathbf{1}}$ & Assignment \\
\hline 3657 & O-H stretching \\
3155 & C-H stretching \\
3050 & C-H stretching \\
2923 & C-H stretching \\
2849 & C-H stretching \\
2362 & O-C-O stretching \\
1633 & C=C stretching \\
1405 & C-H bending \\
1016 & C-O stretching \\
\hline
\end{tabular}

\subsubsection{Zeta Potential of Pyrolysis Residue}

The surface charge of the char particles is dependent on the functional groups. The zeta potential in the range between $-30 \mathrm{mV}$ and $+30 \mathrm{mV}$ indicates the stability of the particles against coalescence. The average surface zeta potential charge of the pyrolysis residue from pretreated ASR was $+10 \pm 3.96 \mathrm{mV}$. As the value and sign indicated, the surface charge of the particles is positive. Comparing with the DRIFT analysis of the pretreated ASR (Figure 4) shows that the hydroxyl groups are present in the pyrolysis residue from the pretreated ASR. From the distribution (Figure 7a) of the surface charge, we noticed that the broad peak started from negative and ending at a positive charge. The plausible explanation might be that the metals in the pyrolysis residue having various surface charges would have resulted in the negative charge. This is demonstrated by the zeta potential measurements on the ash (carbon-removed) from the pyrolysis residues as shown in Figure $7 \mathrm{~b}$. The average zeta potential for the ash was $-27.80 \pm 0.82 \mathrm{mV}$. The high carbon content present in the pyrolysis residue as seen from Table 4 also contributed to the positive charge of the particle. For the leaching of metals from the pyrolysis residue, the surface charge of the particles should be negative, enhancing their dispersion in aqueous media. Hence before the leaching of metals, the removal of carbon content will be needed. 


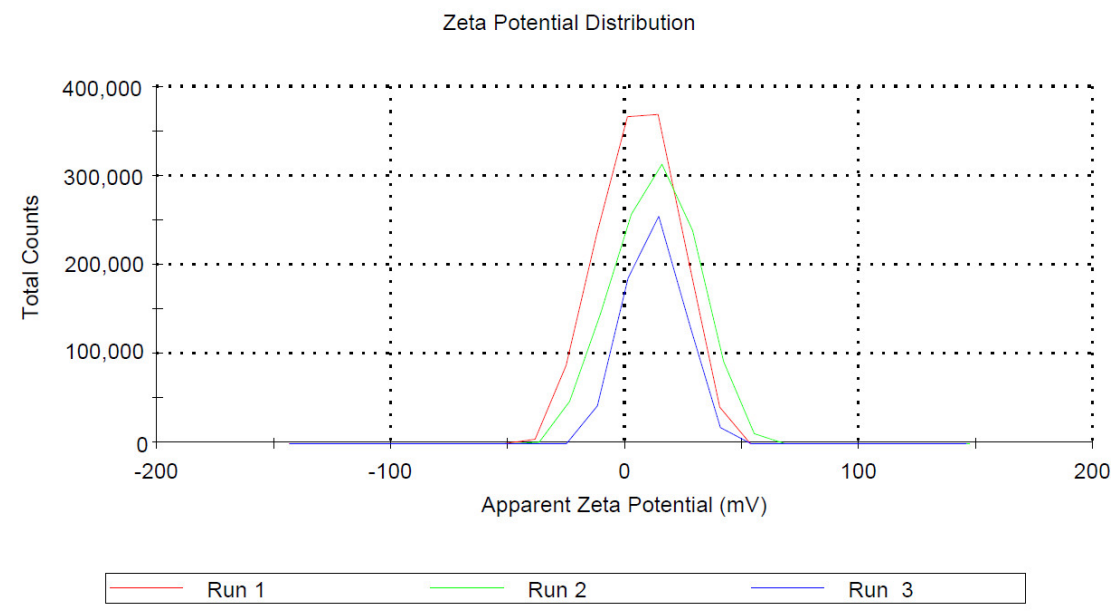

(a)

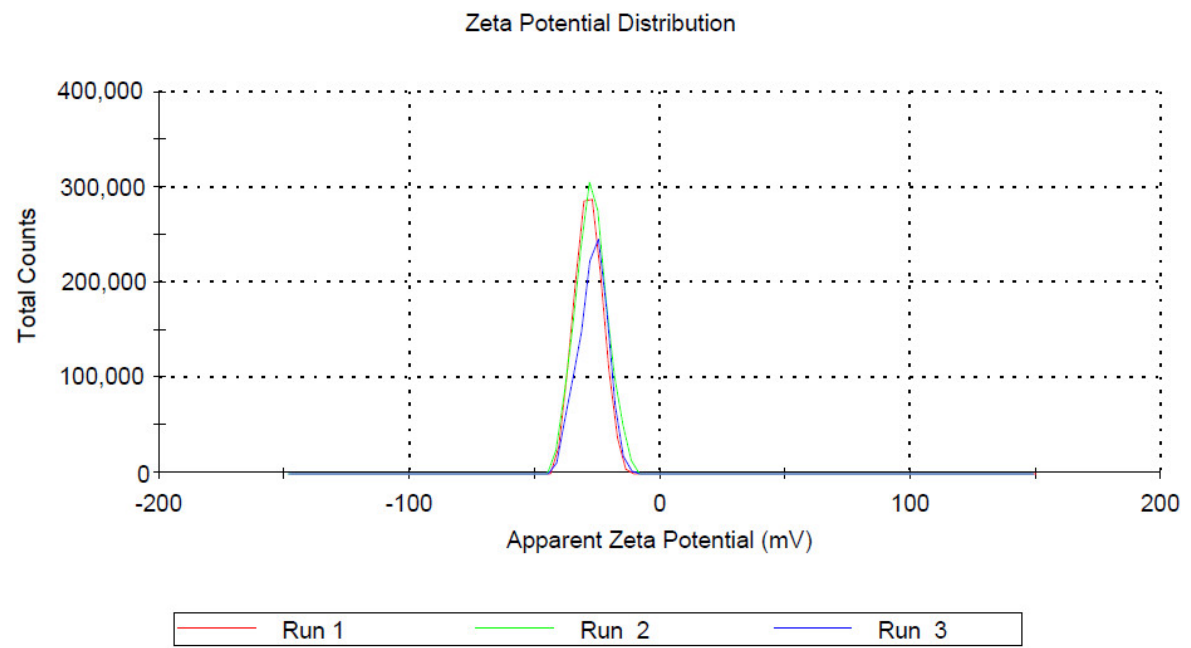

(b)

Figure 7. (a) Distribution of the zeta potential measurement for the pyrolysis residue. (b) Distribution of the zeta potential measurement for ash of the pyrolysis residue.

\subsection{Effect of Particle Size and Heating Rate}

The effect of particle size and heating rate during the pyrolysis of pretreated ASR is studied in detail in this section.

\subsubsection{Effect of Particle Size}

The particle sizes of pretreated ASR ranging between 38-63, 63-90, and 90-106 $\mu \mathrm{m}$ were investigated at a constant heating rate of $10{ }^{\circ} \mathrm{C} / \mathrm{min}$ to study the influence of the particle size in the pyrolysis kinetics. As shown in Figure 8, the TG curves for different particle sizes such as 38-63 $\mu \mathrm{m}, 63-90 \mu \mathrm{m}$, and 90-106 $\mu \mathrm{m}$ depicts the mass loss profile, which decreased with increased particle size. As Figure 5 explicitly shows that mass loss rates at peak temperatures increase with an increase in particle size. It is observed that particle size influences the mass loss rate due to the temperature gradient inside the particle. The devolatilization onset temperature for all particle sizes of pretreated ASR was around $222{ }^{\circ} \mathrm{C}$, as shown in Figure $8 \mathrm{~b}$. The final residue after the pyrolysis was mainly metal components, as described in the previous section (XRF analysis). Based on the devolatilization profile of different particle sizes as shown in Figure 8b, we choose 90-106 $\mu \mathrm{m}$ particle size for further investigation. The mass loss and the devolatilization profile for this particle size are similar to particle size 63-90 $\mu \mathrm{m}$. However, we did not choose 63-90 $\mu \mathrm{m}$ as this particle size as it will require more energy for grinding, sieving, 
and difficulty in feeding. In addition, Figure $8 \mathrm{a}, \mathrm{b}$ do not show any difference between the 63-90 and 90-106-micron particle sizes and therefore are unlikely to show any difference in kinetics.

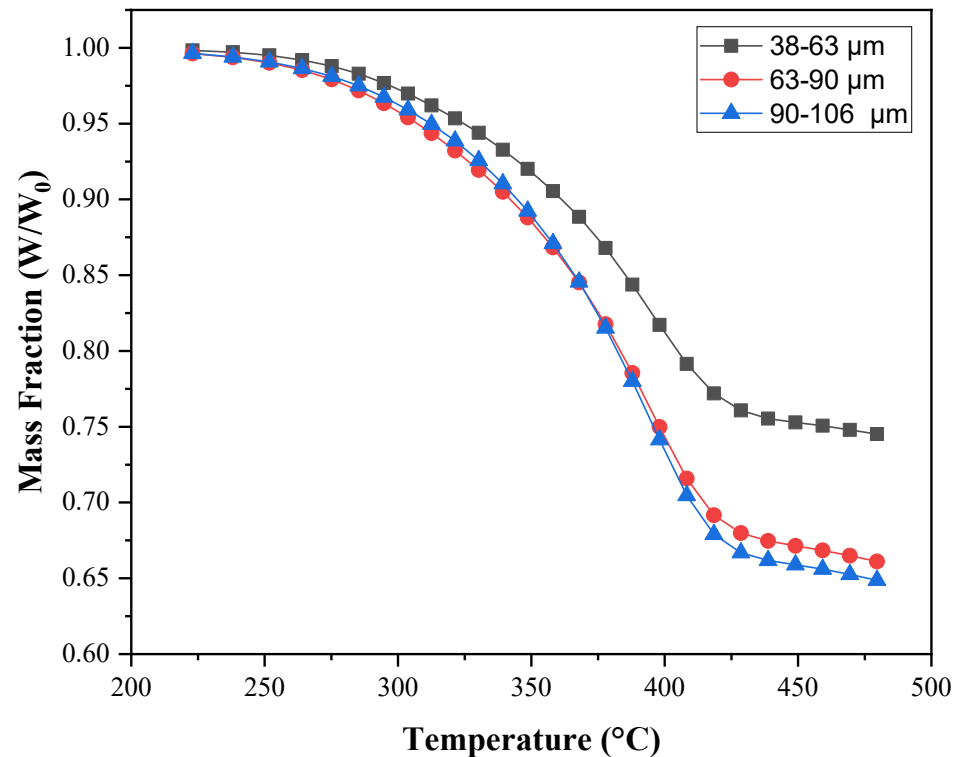

(a)

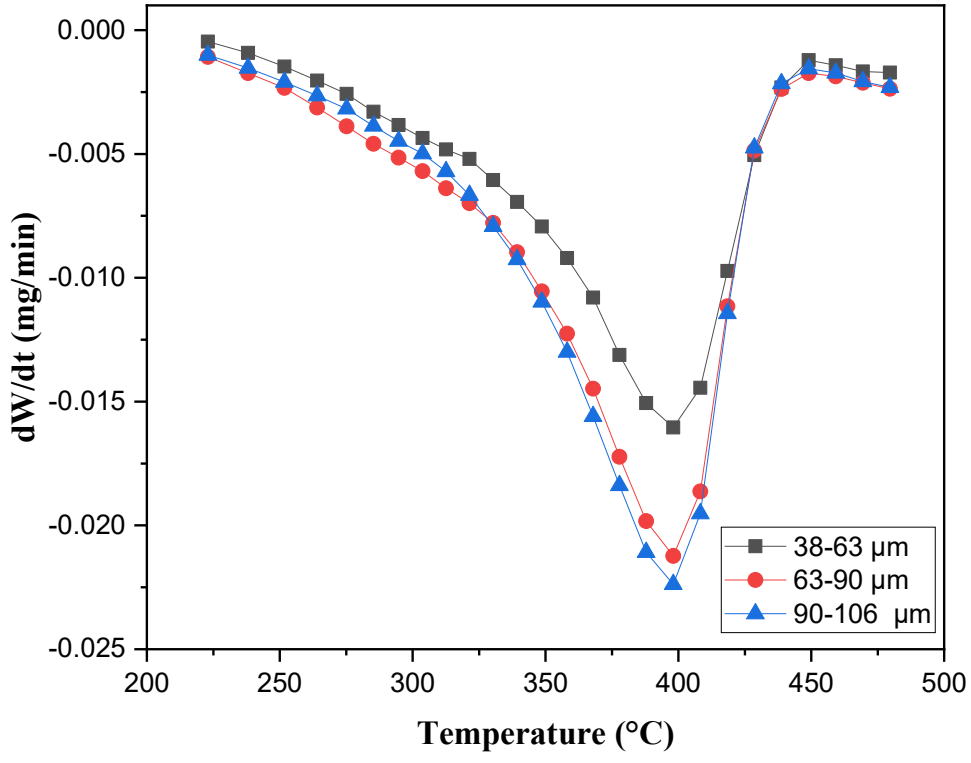

(b)

Figure 8. (a) Effect on particle size on weight loss in the devolatilization range of the pretreated ASR at a constant heating rate $\left(10^{\circ} \mathrm{C} / \mathrm{min}\right)$. (b) Effect on particle size on the differential weight loss in the devolatilization range at a constant heating rate $\left(10^{\circ} \mathrm{C} / \mathrm{min}\right)$.

\subsubsection{Effect of Heating Rate}

The influence of heating rate with the particle size $(90-106 \mu \mathrm{m})$ for three different heating rates, $2^{\circ} \mathrm{C} / \mathrm{min}, 5^{\circ} \mathrm{C} / \mathrm{min}$, and $10^{\circ} \mathrm{C} / \mathrm{min}$, were studied. In this study, we consider a low heating rate based on the recommendation of the ICTAC kinetic committee. The consideration of low heating rate is also justified in Section 3.4, where we mathematically showed that the consideration of low heating rate in this study is in line with a heating rate of a commercial rotary kiln pyrolyser for the slow pyrolysis process. As shown in Figure 9, the TG curves, the mass loss of the sample is observed to decrease with an increase 
in heating rate. Therefore, as seen in the figure, the heating rate impacts the pyrolysis behaviour of the samples.

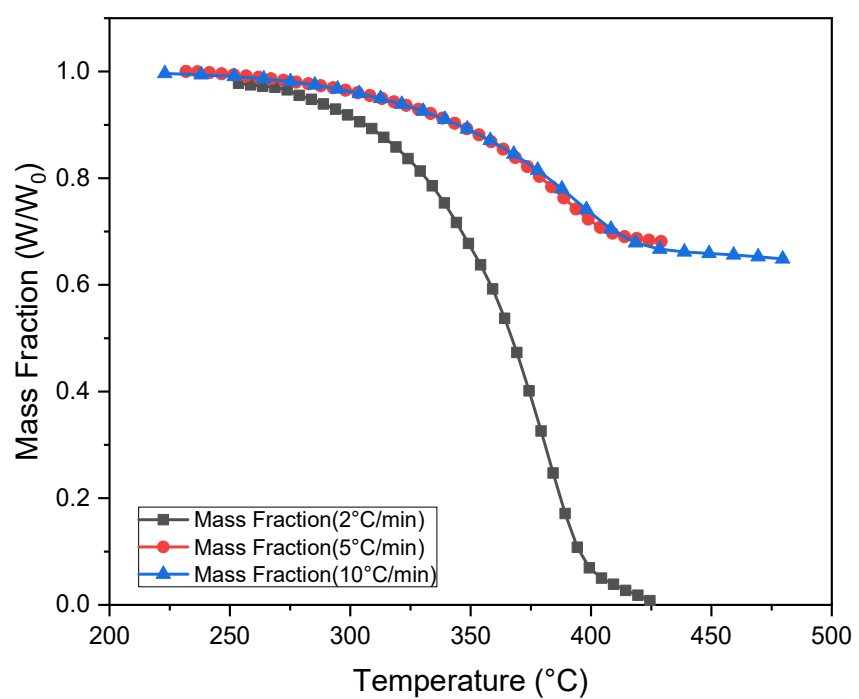

(a)

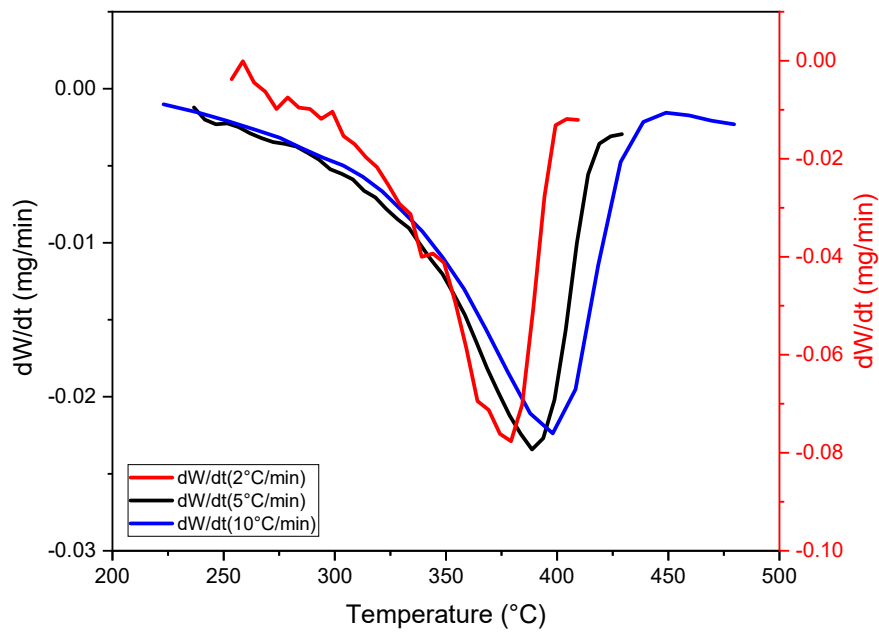

(b)

Figure 9. (a) Effect of different heating rates on weight loss during devolatilization for a given particle size (90-106 $\mu \mathrm{m})$. (b) Effect of different heating rates on differential weight loss during devolatilization for given particle size $(90-106 \mu \mathrm{m})$.

\subsection{Kinetic Model Analysis}

From the results of effect on the particle size of pretreated ASR, 90-106 $\mu \mathrm{m}$ was chosen for kinetic model analysis as pyrolysis of this particle size remained in the kinetic control region. The linearized form of the DTG experimental data was based on Equation (8). Figure 10 depicts the graphical representation of the linearized form of data for the pretreated ASR of particle size of 90-106 $\mu \mathrm{m}$ at different heating rates $\left(2,5\right.$, and $\left.10^{\circ} \mathrm{C} / \mathrm{min}\right)$. The values of activation energy $\left(\mathrm{E}_{a}\right)$, pre-exponential factor $(\mathrm{A})$, reaction order $(\mathrm{n})$, and the correlation coefficient $\left(\mathrm{R}^{2}\right)$ are listed in Table 6 . The activation energy values are 94.5, 66.8, and $49 \mathrm{~kJ} / \mathrm{mol}$ for 2,5 , and $10{ }^{\circ} \mathrm{C} / \mathrm{min}$, respectively. The pre-exponential factor (A) varies in the same magnitude as the activation energy when the temperature increases due to the compensation effect [35]. The correlation coefficient values range between 0.96 and 0.99 for 2,5 , and $10{ }^{\circ} \mathrm{C} / \mathrm{min}$, respectively, indicating good fits. 


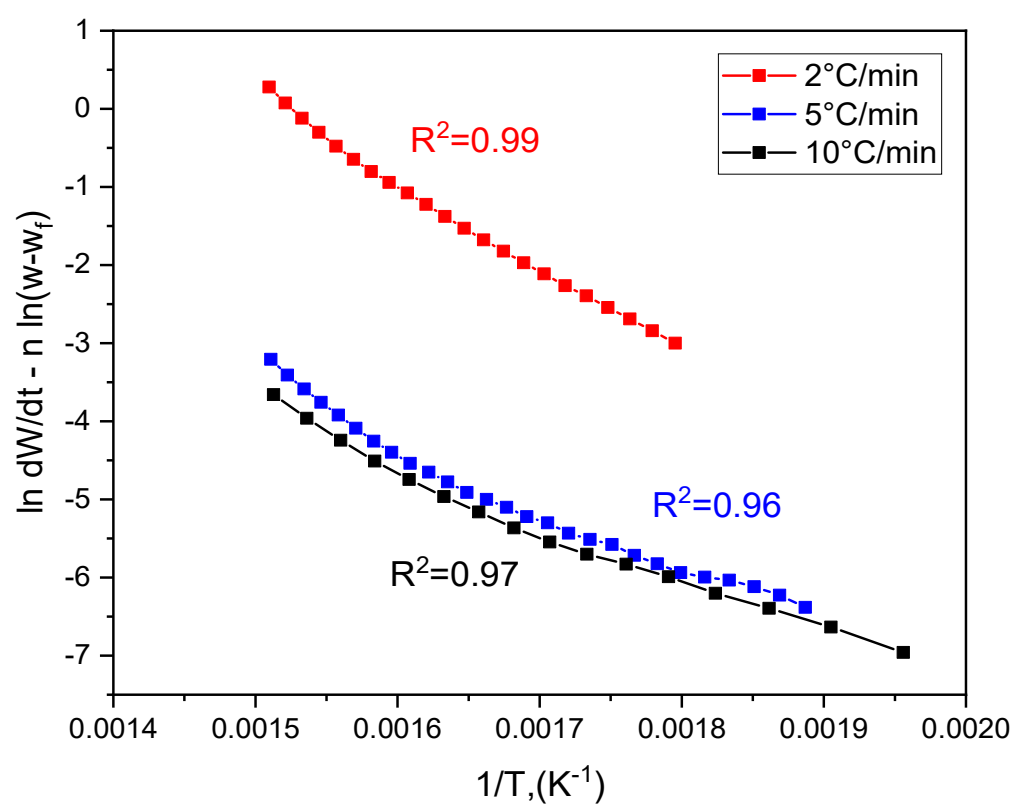

Figure 10. Kinetic data analysis for the pretreated ASR of particle size of 90-106 $\mu \mathrm{m}$ at two different heating rates $\left(2,5\right.$, and $\left.10{ }^{\circ} \mathrm{C} / \mathrm{min}\right)$.

Table 6. Kinetic parameters for the pretreated ASR of particle size of 90-106 $\mu \mathrm{m}$ at three different heating rates $\left(2,5\right.$, and $\left.10{ }^{\circ} \mathrm{C} / \mathrm{min}\right)$.

\begin{tabular}{lccc}
\hline Inetic Parameters & $\mathbf{2}{ }^{\circ} \mathbf{C} / \mathbf{m i n}$ & $\mathbf{5}^{\circ} \mathbf{C} / \mathbf{m i n}$ & $\mathbf{1 0}{ }^{\circ} \mathbf{C} / \mathbf{m i n}$ \\
\hline Reaction order $(\mathrm{n})$ & 0.3 & 0.3 & 0.3 \\
Apparent activation energy $\left(\mathrm{E}_{a}\right), \mathrm{kJ} / \mathrm{mol}$ & 94.54 & 66.8 & 49 \\
Pre-exponential factor $(\mathrm{A}), \mathrm{min}^{-1}$ & $1.05 \times 10^{7}$ & $2.8 \times 10^{4}$ & $1.1 \times 10^{3}$ \\
Correlation co-efficient $\left(\mathrm{R}^{2}\right)$ & 0.99 & 0.96 & 0.97 \\
\hline
\end{tabular}

Selection of Heating Rate for Pyrolysis of Pretreated ASR

The previous section derived the kinetic data for three heating rates $(2,5$, and $10{ }^{\circ} \mathrm{C} / \mathrm{min}$ ). In this section, we estimate the heating rate of these pretreated ASR samples in a commercially rotary kiln pyrolyser if intended to use pretreated ASR as feedstock.

Commercially available rotary kiln pyrolysers are widely used to process waste plastic/MSW for liquid fuel production. The process itself is self-sustaining by utilizing the pyrolysis gas generated during the pyrolysis. However, an external heat source is required during cold start-up.

Typically, commercially available rotary kiln pyrolysers have capacities of 5-10 tons per day for any solid waste. However, this is a slow pyrolysis process, and the total operation time varies from $8-10 \mathrm{~h}$ (including $4-5 \mathrm{~h}$ initial ramping from the cold condition) depending on the nature and loading of the feedstock.

The total operation time can be divided into two stages. The first stage is the ramping to attain initial pyrolysis temperature by using an external energy source. Then, when decomposition temperature is reached, the generated pyrolysis gas is utilized in the system, and the second stage begins. In this stage, most of the product is pyrolyzed, leaving behind the residual solid.

In this section, we consider a 10 ton per day rotary kiln pyrolyser unit to process pretreated ASR for a total operation time of 8 hours. We consider four hours for initial ramping to attain initial pyrolysis temperature and the next four hours for the pyrolysis process. Under this condition, we calculate the probable heating rate that might be valid for commercial rotary kiln pyrolyser during the slow pyrolysis process. The data for calculating the required energy is listed in Table 7. 
The readers should note that in the ramping stage, the heat energy is consumed as sensible heat by the pre-treated ASR (including the metals inside). During the second stage, heat energy is consumed due to the heat of pyrolysis for the breakdown of polymers and as sensible heat by the residual solid.

The heat balance for the entire process can be written as:

$$
\begin{gathered}
Q(\text { Total })=Q(\text { sensible })+Q(\text { Pyrolysis }) \\
Q(\text { sensible })=\text { Mass } * C p(M I X) *(T 2-T 1) \\
Q(\text { Pyrolysis })=\text { Mass } * \text { Volatile fraction } * \text { heat of pyrolysis }+ \\
\text { Mass } * \text { Solid fraction } * C p(\text { solid }) *(T 3-T 2)
\end{gathered}
$$

Table 7. The necessary data for calculating the required energy.

\begin{tabular}{lll}
\hline Parameters & Value & Units \\
\hline Cp (polymers) & 1.67 & $\mathrm{~kJ} / \mathrm{kg} \cdot \mathrm{k}$ \\
Cp (solid) & 1.21 & $\mathrm{~kJ} / \mathrm{kg} \cdot \mathrm{k}$ \\
Cp (MIX) & 1.42 & $\mathrm{~kJ} / \mathrm{kg} \cdot \mathrm{k}$ \\
Mass & 10 & $\mathrm{Ton}$ \\
Heat of Pyrolysis & 301 & $\mathrm{~kJ} / \mathrm{kg}$ \\
Volatile fraction & 0.55 & \\
Solid fraction & 0.45 & $\%$ \\
T1 (Initial temperature) & 15 & ${ }^{\circ} \mathrm{C}$ \\
T2 (End ramping temp) & 300 & ${ }^{\circ} \mathrm{C}$ (Based on Figure 3) \\
T3 (Final temperature) & 400 & ${ }^{\circ} \mathrm{C}$ \\
Ramping time & 4 & $\mathrm{~h}$ \\
Pyrolysis time & 4 & $\mathrm{~h}$ \\
\hline
\end{tabular}

As this process is a batch process, the calculated energy requirement " $Q$ " has a unit of Joule $(J)$. This is the minimum energy required for any particular stage which is supplied through a particular time. As a result, the power required for that particular stage can be calculated based on Equation (12):

$$
P(i)=\frac{Q(i)}{\operatorname{Time}(i)}
$$

Here, " $i$ " is the stage identification. The calculated power $(P)$ has a unit of "watt". The power required can be related to the unsteady temperature profile and can be calculated based on Equation (13):

$$
P(i)=\operatorname{mass}(i) * C p(i) * \frac{d T}{d t}
$$

Here, $\frac{d T}{d t}$ is the heating rate and $C p$ is the specific heat capcity.

The calculated heating rate depends on the thermal properties of ASR, given operation time (ramping/pyrolysis) and independent of ASR mass. Furthermore, we adjust the stage operation time while holding the thermal properties as constant so that the heating rate is near the TGA heating rate. The calculated heating rate is presented in Table 8.

Table 8. Calculated heating rate and required time for the pretreated ASR pyrolysis process.

\begin{tabular}{ccc}
\hline Conditions & Ramping $\left(\mathbf{1 5 - 3 0 0}{ }^{\circ} \mathbf{C}\right)$ & Pyrolysis $\left(\mathbf{3 0 0 - 4 0 0}{ }^{\circ} \mathbf{C}\right)$ \\
\hline$(4+4) \mathrm{h}$ & 1.21 & 1.70 \\
$(2.5+3.5) \mathrm{h}$ & 1.91 & 1.93 \\
\hline
\end{tabular}

As seen in Table 8 , the calculated heating is close to $2{ }^{\circ} \mathrm{C} / \mathrm{min}$ regardless of the operation time of the pyrolyser. As a result, the calculated kinetics parameter for $2{ }^{\circ} \mathrm{C} / \mathrm{min}$ 
in Section 3.8 might be more appropriate and valid if used for scaling up the pretreated ASR pyrolysis process.

\section{Conclusions}

This work proposed a new procedure for the pretreatment of ASR to introduce 'homogeneity' for easier feeding into the pyrolysis plant. By pretreatment of ASR, there is not much loss in volatiles, which can be harnessed for energy recovery. The DRIFT spectroscopy results confirm the presence of polymers in the pretreated ASR that can be converted into pyrolytic products during the pyrolysis process. The elemental composition of pretreated ASR reveals that the residual metals are not oxidized from their original state. This work also investigates the thermal decomposition characteristics of pretreated ASR performed in a thermogravimetric analyzer according to the ICTAC kinetics committee recommendations. The effect of varying particle size and heating rate was also studied. After that, a kinetic model was used to estimate the kinetic parameters, the activation energy, the pre-exponential factor, and the reaction order for all three heating rates at the given particle size of 90 to $106 \mu \mathrm{m}$. Then, the heating rate required in a commercial scale rotary kiln pyrolyser for pretreated ASR pyrolysis was found by mathematical calculation. The calculated heating rate was on par with the obtained kinetics parameter for $2{ }^{\circ} \mathrm{C} / \mathrm{min}$. The wastes of similar nature to the automotive shredder residue, such as municipal solid waste, can also be combined for processing through slow pyrolysis.

The main conclusions of this study are as follows:

- The heterogeneous ASR (as received) was pretreated to bring about homogeneity in the sample for easier feeding.

- The TGA analysis showed that the decomposition occurs at a temperature range between $216{ }^{\circ} \mathrm{C}$ and $450{ }^{\circ} \mathrm{C}$. It was also observed that particle size influences the final residue's yield as mass loss decreased as the particle size increased.

- The activation energy obtained from the kinetic model for $2{ }^{\circ} \mathrm{C} / \mathrm{min}$ for the particle size 90-106 $\mu \mathrm{m}$ was $94.5 \mathrm{~kJ} / \mathrm{mol}$.

- The calculated heating rate for pretreated ASR pyrolysis was $2{ }^{\circ} \mathrm{C} / \mathrm{min}$ to process in a commercial rotary kiln pyrolyser.

Author Contributions: Conceptualization, S.K.V., M.A.K. and S.B.; investigation, S.K.V., M.A.K. and M.H.U.; writing—original draft preparation, S.K.V.; writing-review and editing, M.A.K. and S.B.; project administration, S.B.; All authors have read and agreed to the published version of the manuscript.

Funding: This article is for the project funded by the ARC Discovery project Thermal isolation: A novel pathway to transforming complex waste (DP180101436). S.V acknowledges the Australian Research Council for her living scholarship and Monash University for her tuition scholarship.

Institutional Review Board Statement: Not applicable.

Informed Consent Statement: Not applicable.

Data Availability Statement: Not applicable.

Acknowledgments: Zeta Potential measurements— “This work was performed in part at the Melbourne Centre for Nanofabrication $(\mathrm{MCN})$ in the Victorian Node of the Australian National Fabrication Facility (ANFF)".

Conflicts of Interest: The authors declare no conflict of interest. The funders had no role in the design of the study; in the collection, analyses, or interpretation of data; in the writing of the manuscript, or in the decision to publish the results.

\section{References}

1. Bruyère, D.; Simon, S.; Haas, H.; Conte, T.; Menad, N.-E. Cryogenic ball milling: A key for elemental analysis of plastic-rich automotive shedder residue. Powder Technol. 2016, 294, 454-462. [CrossRef]

2. Buekens, A.; Zhou, X. Recycling plastics from automotive shredder residues: A review. J. Mater. Cycles Waste Manag. 2014, 16, 398-414. [CrossRef] 
3. Morselli, L.; Santini, A.; Passarini, F.; Vassura, I. Automotive shredder residue (asr) characterization for a valuable management. Waste Manag. 2010, 30, 2228-2234. [CrossRef]

4. Cossu, R.; Lai, T. Washing treatment of automotive shredder residue (asr). Waste Manag. 2013, 33, 1770-1775. [CrossRef]

5. Fiore, S.; Ruffino, B.; Zanetti, M.C. Automobile shredder residues in Italy: Characterization and valorization opportunities. Waste Manag. 2012, 32, 1548-1559. [CrossRef] [PubMed]

6. Gonzalez-Fernandez, O.; Hidalgo, M.; Margui, E.; Carvalho, M.L.; Queralt, I. Heavy metals' content of automotive shredder residues (asr): Evaluation of environmental risk. Environ. Pollut. 2008, 153, 476-482. [CrossRef] [PubMed]

7. Redin, L.A.; Hjelt, M.; Marklund, S. Co-combustion of shredder residues and municipal solid waste in a swedish municipal solid waste incinerator. Waste Manag. Res. 2001, 19, 518-525. [CrossRef]

8. Lombardo, G.; Ebin, B.; Steenari, B.-M.; Alemrajabi, M.; Karlsson, I.; Petranikova, M. Comparison of the effects of incineration, vacuum pyrolysis and dynamic pyrolysis on the composition of nmc-lithium battery cathode-material production scraps and separation of the current collector. Resour. Conserv. Recycl. 2021, 164, 105142. [CrossRef]

9. Liu, J.; Huang, L.; Zou, H.; Xie, W.; Evrendilek, D.E.; Luo, G.; Ninomiya, Y. Do fecl3 and fecl3/cao conditioners change pyrolysis and incineration performances, emissions, and elemental fates of textile dyeing sludge? J. Hazard. Mater. 2021, 413 , 125334. [CrossRef]

10. Day, M.; Cooney, J.D.; Shen, Z. Pyrolysis of automobile shredder residue: An analysis of the products of a commercial screw kiln process. J. Anal. Appl. Pyrolysis 1996, 37, 49-67. [CrossRef]

11. Galvagno, S.; Fortuna, F.; Cornacchia, G.; Casu, S.; Coppola, T.; Sharma, V.K. Pyrolysis process for treatment of automobile shredder residue: Preliminary experimental results. Energy Convers. Manag. 2001, 42, 573-586. [CrossRef]

12. Marco, I.D.; Caballero, B.; Torres, A.; Laresgoiti, M.F.; Chomón, M.J.; Cabrero, M.A. Recycling polymeric wastes by means of pyrolysis. J. Chem. Technol. Biotechnol. 2002, 77, 817-824. [CrossRef]

13. Roy, C.; Chaala, A. Vacuum pyrolysis of automobile shredder residues. Resour. Conserv. Recycl. 2001, 32, 1-27. [CrossRef]

14. Shen, Z.; Day, M.; Cooney, J.D.; Lu, G.; Briens, C.L.; Bergougnou, M.A. Ultrapyrolysis of automobile shredder residue. Can. J. Chem. Eng. 1995, 73, 357-366. [CrossRef]

15. Zolezzi, M.; Nicolella, C.; Ferrara, S.; Iacobucci, C.; Rovatti, M. Conventional and fast pyrolysis of automobile shredder residues (asr). Waste Manag. 2004, 24, 691-699. [CrossRef]

16. Mayyas, M.; Pahlevani, F.; Maroufi, S.; Liu, Z.; Sahajwalla, V. Waste conversion into high-value ceramics: Carbothermal nitridation synthesis of titanium nitride nanoparticles using automotive shredder waste. J. Environ. Manag. 2017, 188, 32-42. [CrossRef]

17. Vermeulen, I.; Van Caneghem, J.; Block, C.; Baeyens, J.; Vandecasteele, C. Automotive shredder residue (asr): Reviewing its production from end-of-life vehicles (elvs) and its recycling, energy or chemicals' valorisation. J. Hazard. Mater. 2011, 190, 8-27. [CrossRef]

18. Vyazovkin, S.; Burnham, A.K.; Criado, J.M.; Pérez-Maqueda, L.A.; Popescu, C.; Sbirrazzuoli, N. Ictac kinetics committee recommendations for performing kinetic computations on thermal analysis data. Thermochim. Acta 2011, 520, 1-19. [CrossRef]

19. Han, B.; Chen, Y.; Wu, Y.; Hua, D.; Chen, Z.; Feng, W.; Yang, M.; Xie, Q. Co-pyrolysis behaviors and kinetics of plastics-biomass blends through thermogravimetric analysis. J. Therm. Anal. Calorim. 2014, 115, 227-235. [CrossRef]

20. Chhabra, V.; Bhattacharya, S.; Shastri, Y. Pyrolysis of mixed municipal solid waste: Characterisation, interaction effect and kinetic modelling using the thermogravimetric approach. Waste Manag. 2019, 90, 152-167. [CrossRef]

21. Vyazovkin, S.; Burnham, A.K.; Favergeon, L.; Koga, N.; Moukhina, E.; Pérez-Maqueda, L.A.; Sbirrazzuoli, N. Ictac kinetics committee recommendations for analysis of multi-step kinetics. Thermochim. Acta 2020, 689, 178597. [CrossRef]

22. Conesa, J.A.; Rey, L.; Aracil, I. Modeling the thermal decomposition of automotive shredder residue. J. Therm. Anal. Calorim. 2016, 124, 317-327. [CrossRef]

23. Biney, P.O.; Gyamerah, M.; Shen, J.; Menezes, B. Kinetics of the pyrolysis of arundo, sawdust, corn stover and switch grass biomass by thermogravimetric analysis using a multi-stage model. Bioresour. Technol. 2015, 179, 113-122. [CrossRef] [PubMed]

24. Notarnicola, M.; Cornacchia, G.; De Gisi, S.; Di Canio, F.; Freda, C.; Garzone, P.; Martino, M.; Valerio, V.; Villone, A. Pyrolysis of automotive shredder residue in a bench scale rotary kiln. Waste Manag. 2017, 65, 92-103. [CrossRef] [PubMed]

25. Evangelopoulos, P.; Sophonrat, N.; Jilvero, H.; Yang, W. Investigation on the low-temperature pyrolysis of automotive shredder residue (asr) for energy recovery and metal recycling. Waste Manag. 2018, 76, 507-515. [CrossRef] [PubMed]

26. Williams, K.S.; Khodier, A. Meeting eu elv targets: Pilot-scale pyrolysis automotive shredder residue investigation of pahs, pcbs and environmental contaminants in the solid residue products. Waste Manag. 2020, 105, 233-239. [CrossRef]

27. Mancini, G.; Viotti, P.; Luciano, A.; Fino, D. On the asr and asr thermal residues characterization of full scale treatment plant. Waste Manag. 2014, 34, 448-457. [CrossRef]

28. Mayyas, M.; Pahlevani, F.; Handoko, W.; Sahajwalla, V. Preliminary investigation on the thermal conversion of automotive shredder residue into value-added products: Graphitic carbon and nano-ceramics. Waste Manag. 2016, 50, 173-183. [CrossRef] [PubMed]

29. Shibayama, A.; Otomo, T.; Takasaki, Y.; Cao, Y.; Murakami, T.; Watanabe, K.; Inoue, H. Separation and recovery of valuable metals from automobile shredder residue (asr) fly ash by wet processing. Int. J. Soc. Mater. Eng. Resour. 2006, 13, 54-59. [CrossRef]

30. Noda, I.; Dowrey, A.E.; Haynes, J.L.; Marcott, C. Group Frequency Assignments for Major Infrared Bands Observed in Common Synthetic Polymers. In Physical Properties of Polymers Handbook; Springer: New York, NY, USA, 2007; pp. $395-406$. 
31. Hamerton, I. Atlas of plastics additives: Analysis by spectrometric methods. DO Hummel. Springer-Verlag, Berlin, 2002. pp 537, ISBN 3-540-42414-8. Polym. Int. 2004, 53, 355-356. [CrossRef]

32. Ahmad, I.; Khan, M.I.; Khan, H.; Ishaq, M.; Tariq, R.; Gul, K.; Ahmad, W. Pyrolysis study of polypropylene and polyethylene into premium oil products. Int. J. Green Energy 2015, 12, 663-671. [CrossRef]

33. Świechowski, K.; Syguła, E.; Koziel, J.A.; Stępień, P.; Kugler, S.; Manczarski, P.; Białowiec, A. Low-temperature pyrolysis of municipal solid waste components and refuse-derived fuel-Process efficiency and fuel properties of carbonized solid fuel. Data 2020, 5, 48. [CrossRef]

34. Li, K.; Lee, S.W.; Yuan, G.; Lei, J.; Lin, S.; Weerachanchai, P.; Yang, Y.; Wang, J.-Y. Investigation into the catalytic activity of microporous and mesoporous catalysts in the pyrolysis of waste polyethylene and polypropylene mixture. Energies 2016, 9, 431. [CrossRef]

35. Ornaghi, H.L.; Poletto, M.; Zattera, A.J.; Amico, S.C. Correlation of the thermal stability and the decomposition kinetics of six different vegetal fibers. Cellulose 2014, 21, 177-188. [CrossRef] 